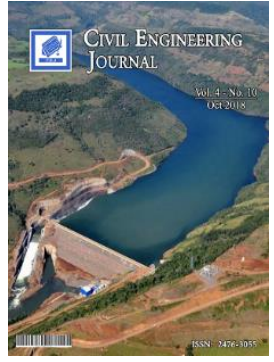

\title{
Effectiveness of Green Roofs and Green Walls on Energy Consumption and Indoor Comfort in Arid Climates
}

\author{
Sherine M. Wahba a ${ }^{\text {a }}$ Basil A. Kamel ${ }^{\text {b }}$, Khaled M. Nassar ${ }^{c}$, Ahmed S. Abdelsalam ${ }^{\text {d* }}$ \\ ${ }^{a}$ Professor, Architectural Engineering Department, Cairo University, Office: SSE - 1047, Egypt. \\ ${ }^{b}$ Professor, Architectural Engineering Department, American University in Egypt, Office: SSE - 1084, Egypt. \\ ${ }^{c}$ Professor, Architectural Engineering Department, American University in Egypt, Office: SSE - 1139, Egypt. \\ ${ }^{d}$ Ph.D Candidate, Architectural Engineering Department, Cairo University, Egypt. \\ Received 11 July 2018; Accepted 30 September 2018
}

\begin{abstract}
Increased urbanization have many negative effects on human well-being, city infrastructure, electricity usage and the increase of indoor temperatures. A solution may be to retrofit existing buildings, with implementing a vegetated layer to roofs and walls, this may enhance building performance, reduce consumption and improve indoor comfort. Cities with tall buildings may be more adequate to implement a green-wall as it have more area to make impact. This paper examines the energy reduction advantages of adding greenery on buildings in the hot arid climate of Egypt by considering three typical types of residential buildings in the city of Cairo as a case study. Design builder software was selected to stimulate the buildings chosen in this research. The results shows that an extensive soil thickness of $15 \mathrm{~cm}$ performs better in the arid climates. electricity consumption for the base case is $52 \mathrm{kWh} / \mathrm{m} 2$ annually when used a traditional external envelop and dropped to $43 \mathrm{kWh} / \mathrm{m} 2$ when a vegetated layer added to the whole building (roof \& wall), annual electricity consumption reduced by $17 \%$ to $25 \%$ per annum when added a vegetated layer. In addition to enhancing the indoor thermal comfort by $3 \mathrm{PMV}$ values and indoor air temperature by $5^{\circ} \mathrm{C}$.

Keywords: Arid Climate; Energy Consumption; Indoor Thermal Comfort; Carbon Offset; Green Wall; Green Roof.
\end{abstract}

\section{Introduction}

Today Urban Cities face energy and environmental challenges due to increased population, higher urbanization [1, 2]. These challenges include shortage in natural resources, increased energy demand and global warming [3-5]. Global warming is the main environmental concern for the world which is leading to sea level rise and climate change. Climate change caused many changes like seasonal disorder including frequent and more severe weather related disasters such as flooding, storms, droughts and wildfires. In 2015, The United Nations Climate Change Conference confirmed the realization of the issue globally and the need to tackle environmental problems. The building sector has a big responsibility as it acquires high consumption rates in global energy and environmental scenarios. It is responsible for $40 \%$ of the overall energy consumption, $40 \%$ of harmful emissions [6-9]. The building sector need to play a vital role in the sustainability act, there is a great potential to reverse negative impact if appropriate methods are considered during construction [10]. Sustainable construction have become an inevitable choice for any developer. Green buildings should promote a better human well-being, better material choice to ensure better indoor quality. In addition to efficient use of resources to reduce pollution and waste.

* Corresponding author: a_abdelsalam@aucegypt.edu

dol http://dx.doi.org/10.28991/cej-03091158

$>$ This is an open access article under the CC-BY license (https://creativecommons.org/licenses/by/4.0/).

(C) Authors retain all copyrights. 
The built environment is the largest part of the physical and economic human-made capital [11], where the construction sector itself constitutes a major part of the gross national product (GNP) [12] and accounts for $40 \%$ of the world's resource and energy use [13]. In Egypt, the sector is a particularly significant contributor to the economy (averaging at 25\% of the GNP) [14] and is also a key user of energy. It is thought that the built environment in Egypt is responsible for $26 \%$ of the total overall national energy consumption, $62 \%$ of the total electricity consumption (Figure 1) and around $70 \%$ of resultant $\mathrm{CO} 2$ emissions [15]. It is therefore important that the sector be considered a key target of energy consumption policies. In recent years, due to the growth of the consumer base, a high rate of rural electrification, increased use of electrical appliances and the Urban Heat Island effect (UHI) affecting major urban centers, the domestic building sector, in particular, has become the main consumer of electricity in the country. The use of air conditioning (AC) units has increased dramatically over the past years, look Figure 1. Official statistics indicate that the number of AC units rose from 196,000 in 1999 to three million in 2009, and then doubled to six million units by 2012 . The use of these devices also in turn worsens the environment through the release of waste heat into urban canyons.

Third world countries still underestimate the importance of activating building codes to enhance the overall performance of buildings; retrofitting of existing buildings mainly focus on structural aspects. Most of residential developers in Cairo uses the minimum expenses to construct a building and ignores any performance codes available. In return, buildings consumes more energy, produce more operational pollutants and provide an uncomfortable indoor thermal environment for the occupants [16]. Available codes must be utilized and used. This could be a condition for issuing the construction permit; however, corruption and little awareness in local councils is causing cities a massive amount of deterioration. Building's energy codes is an important aspect to ensure a sustainable life for the building. In 2009, Housing and Building National Research Center in Egypt [17] has published many codes, one of them for energy efficiency in residential and commercial buildings. The code is very detailed and may need a simpler version to be easy to use. Energy consumption in Egyptian public buildings, including administrative, educational and health buildings is the second largest type after residential [18]. Air conditioning in residential buildings in Egypt consumes about 56\% of total energy per annum, [19].

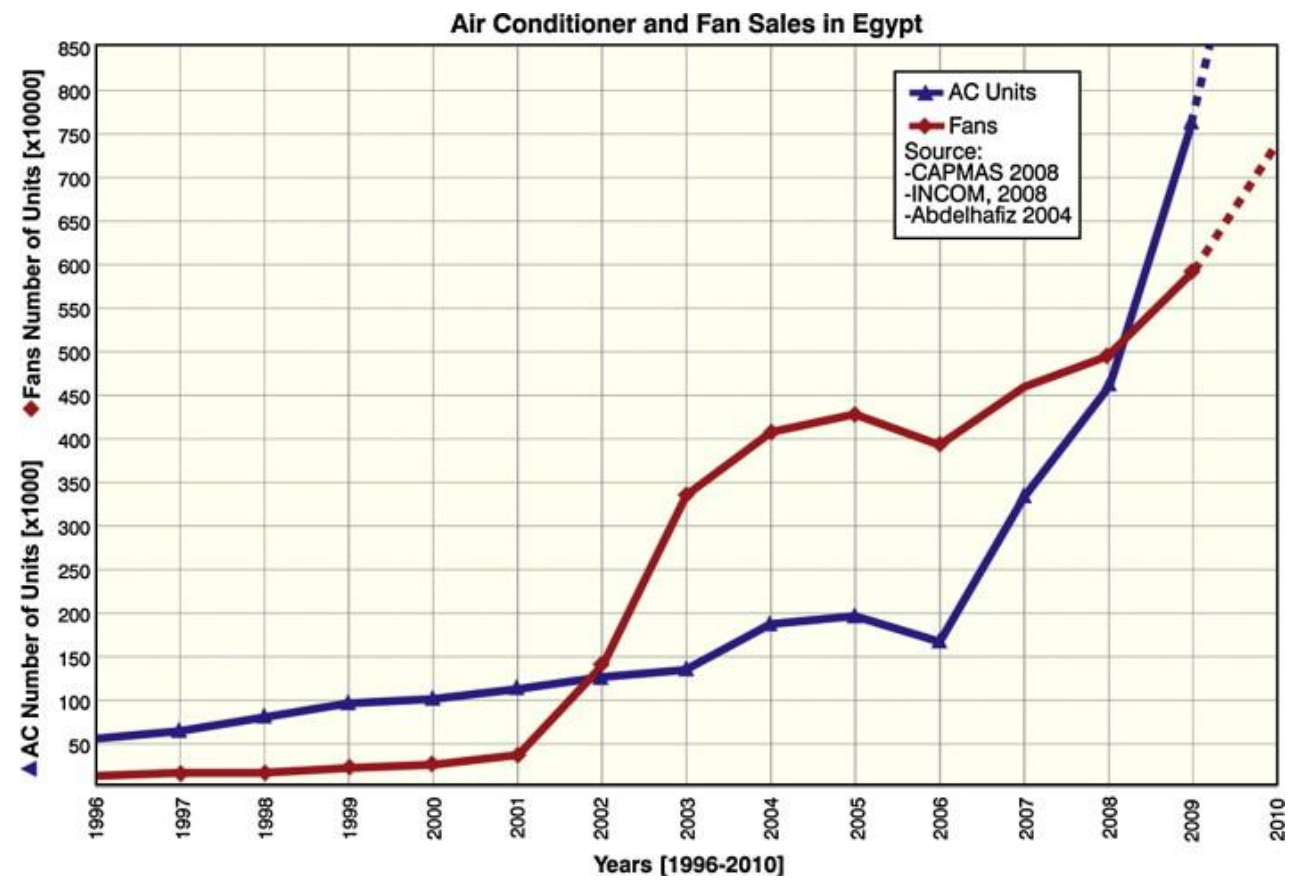

Figure 1. Air-conditioning and fans sales in Egypt [20]

Adding green elements to any urban area is proved to be an effective strategy with numerous benefits to enhance the city's ecosystem, also mitigate the urban heat island measures. Many researches over the past decade investigated the impact of greenery when added to cities; especially trees, studies shown how effective a tree can be compared to air conditioning units. A study concluded that one tree is as effective and equal to 60 air conditioning units. Greenery have proved to improve thermal comfort at the local scale [21-25]. Since roofs represent a high portion of the exposed urbanized area, green roofs have gained widespread attention for their accountable impact on reducing energy consumption, also for their impact on modifying urban climate. Santamouris published many researches about the topic and recently presented a state-of-the-art assessment of green roofs [26]. It's proved that whenever vegetative, or green roofs are installed in high- or medium-rise buildings, there is a direct impact on energy use and urban heat island mitigation potential [27-29]. 
Thermal efficiency caused by green roofs varied, depending on the climate condition and building characteristics. The topic have been extensively studied. Results shows the accountable impact of a green roof to moderate energy consumption [30]. Walls also occupy a high percentage of the total urban surface, potentially greater than the space available for green roofs. Green walls as well can regulate the total energy consumption and reduce cooling load also improve indoor thermal comfort [31-35]. In addition, green walls are more effective in moderating outdoor urban climate than green roofs, studies shown street temperature are lower when a green wall is implemented on a near building [36, 37]; their impact on a city's climate and indoor comfort however has not been widely investigated.

In 2017, a study reported an exclusive summery of green roofs potential, on reduction of the urban heat island effect, reduction of urban air pollution, and reduction of building energy consumption. It concluded that 17 studies reported green roof cooling potential on streets around, ranging between $0.03-3 \mathrm{C}^{\circ}$, four detailed contamination removal at rooftop level, extending between $0.42-9.1 \mathrm{~g} / \mathrm{m}^{2}$ every year, and 41 studies gave an account of building energy consumption, of which 20 were equivalent and asserted changes in annual consumption ranging between an expansion of $7 \%$ to a $90 \%$ decline. The expansive ranges in archived adequacy are attributed to heterogeneity in setting and outline parameters of the distinguished examinations. Investigation of the recognized examinations recommends that a few parameters are of key significance for the adequacy however additionally inquire about is expected to clear up the unpredictable connection between biological system benefit viability and the parameters impacting it [38].

In this paper, through a case study conducted in Cairo, Egypt, the direct effects of green walls and green roofs will be investigated. A typical residential tower will implement a green roof and a green wall to modify a building's thermal environment, carbon emissions. This study will compare the electricity consumption and savings potential of green roof and green walls when implemented in arid climate for different latitudes. The study will investigate the effect of green roofs and walls on the thermal comfort of a single conditioned zone in arid climate. This was achieved by building energy simulation, DesignBuilder.

\section{Methodology}

The present study aims to investigate the effect of green infrastructure on electricity consumption, thermal comfort and carbon emission reduction via its effect on annual energy consumption and air temperature in a typical urban neighborhood in Cairo. High-density city situated in the middle of Egypt $\left(30.04^{\circ} \mathrm{N}, 31.23^{\circ} \mathrm{E}\right)$ with an average altitude of $74 \mathrm{~m}$. Electricity is accounted annually in Kwh while indoor comfort investigation is during the hottest day 2nd of August and is calculated using PMV, and air temperature. Cairo experiences a hot-arid climate with average temperature around $35{ }^{\circ} \mathrm{C}$ and humidity of $56 \%$.

\subsection{Description of Simulation Tools}

DesignBuilder is a whole building simulation software tool. It uses energy plus's open source code to simulate the indoor micro-climate and energy use. The program enable users to model a full detailed buildings. Modelling interface is user friendly and a descriptive content is provided to help users. Users model building with full description to every building system used; from schedules, construction materials to lighting, HVAC system and openings percentages. Sailor [39] provided DesignBuilder with a validated model of a green roof, based on heat balance equation. Software accounts for Irrigation dynamics that affect the vegetated layer performance, due to evaporation and transpiration. It's agreed that the software is accepted to assess the green roof performance. The green roof material can be used on walls to act as a green wall. Irrigation isn't effective with green walls. Software enables the user to identify many properties for any vegetated layer including soil depth, soil conductivity, plant density, plant height, stomatal conductance and embodied carbon [40-42]. Trail version of DesignBuilder is available at https://designbuilder.co.uk.

\subsection{Scenarios Setup}

Simulation sequence goes as follows; simulate building performance and deduce most effective green layer to reduce electricity, carbon emission and enhance indoor thermal comfort. A Hypothetical building comes with $3 \mathrm{~m}$ height per floor and area of $260 \mathrm{~m}$. sq. (two flats per floor) and three different heights 5 Floors, 10 Floors and 15 Floors, look Table 1. All simulations will implement a green roof and wall (100\% coverage), then, will compare it with a base case (bare wall). A $15 \mathrm{~cm}$ soil thickness (extensive) is set for any green layer (roof or wall), as it is the most efficient thickness in arid climates [43], Table 2 present the properties of any green layer used in the simulation. Building systems and materials description in DesignBuilder are presented in Table 3 and 4. The weather data of Cairo was derived from EnergyPlus climate file database of the U.S. Department of Energy. The outside Dry-Bulb Temperature, wind speed and relative humidity are all enforced via DesignBuilder preinstalled weather file. 
Table 1. Displays the simulation sequence and scenario

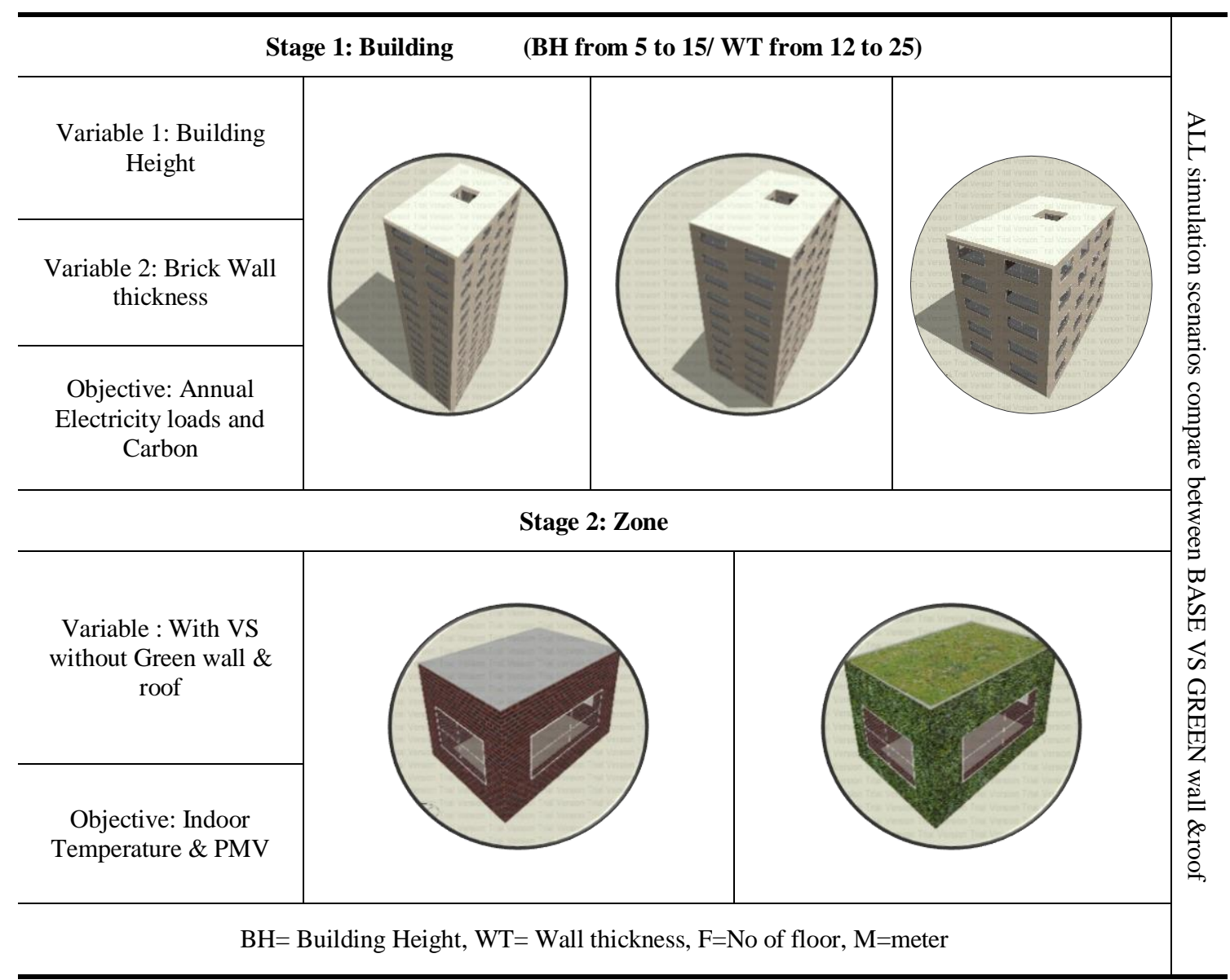

Table 2. Describes green layer properties for the simulation

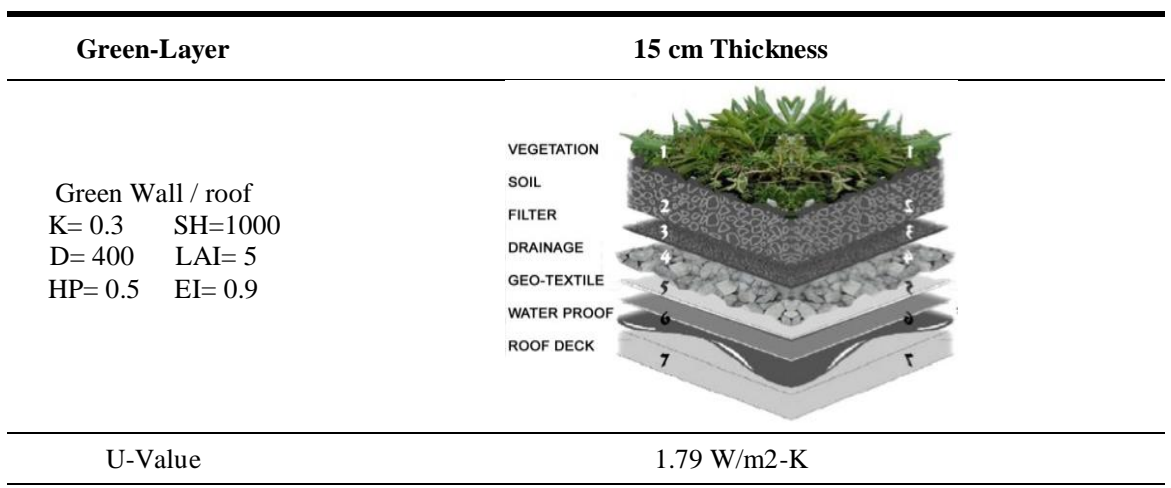

$\mathrm{K}$ is Thermal Conductivity in $\left(\mathrm{W} / \mathrm{m}^{2}-\mathrm{K}\right)$, SH is Specific Heat in $(\mathrm{J} / \mathrm{kg}-\mathrm{K})$, D is Density in $\left(\mathrm{kg} / \mathrm{m}^{3}\right)$, LAI is Leaf Area Index, HP is Height of plants in (m) and EI is Emissivity, U-Value in W/ $\left(\mathrm{m}^{2}-\mathrm{K}\right)$

Table 3. Building Characteristics for Simulation Scenario

\begin{tabular}{cc}
\hline Function & Rate \\
\hline occupancy rate & $0.0196($ people $/ \mathrm{m} 2)-$ residential \\
walls construction & $12 \& 25$ brickwork - outer leaf \\
lighting energy & $1.00 \mathrm{w} / \mathrm{m} 2-100$ lux \\
HVAC & split with no fresh air \\
openings & $30 \%$ wall to window ratio - double glazing clear $6 \mathrm{~mm} / 6 \mathrm{~mm}$ \\
infiltration & model infiltration 0.7 (ac/h)
\end{tabular}


Table 4. Roof and wall layers modeled in the software and total u-value

\begin{tabular}{cccc}
\hline Roof type & Bass roof & Wall type & Bass wall \\
\hline roof tile & $2 \mathrm{~cm}$ & external painting & $2 \mathrm{~mm}$ \\
sand and mortar & $6 \mathrm{~cm}$ & external render & $2 \mathrm{~cm}$ \\
thermal break & $5 \mathrm{~cm}$ & red brick & $12 \mathrm{~cm}-25 \mathrm{~cm}$ \\
water proofing & $0.5 \mathrm{~cm}$ & internal render & $2 \mathrm{~cm}$ \\
sloped concrete & $7 \mathrm{~cm}$ & internal painting & $2 \mathrm{~mm}$ \\
reinforced concrete $1 \%$ & $15 \mathrm{~cm}$ & & $0.6-0.8 \mathrm{w} / \mathrm{m}^{2}-\mathrm{k}$ \\
\hline
\end{tabular}

\section{Results and Discussion}

\subsection{Electricity Savings and Validation}

Construction in Egypt doesn't follow the Egyptian Code for improving the Energy Efficiency in residential buildings. By code external envelop for conditioned residential towers in greater Cairo capital should account for an average of 1 $\mathrm{W} / \mathrm{m}^{2}-\mathrm{K}$, depending on orientation. However, almost all residential developers apply only 12 or $25 \mathrm{~cm}$ of red brick with $\mathrm{U}$-value of 0.42 and $0.5 \mathrm{~W} / \mathrm{m}^{2}-\mathrm{K}$, to enlarge area of dwellings and maximize sales profits. This is a main cause of indoor discomfort and increased electricity usage for air cooling. This research aim to find a realistic retrofitting solution by adding a green layer to the existing walls and roofs. Table 5 summarizes the results of the simulated energy performance for the base case model and the green layer options applied on three buildings with 5 different envelop options.

Table 5. Annual electricity results for the three buildings with and without greenery

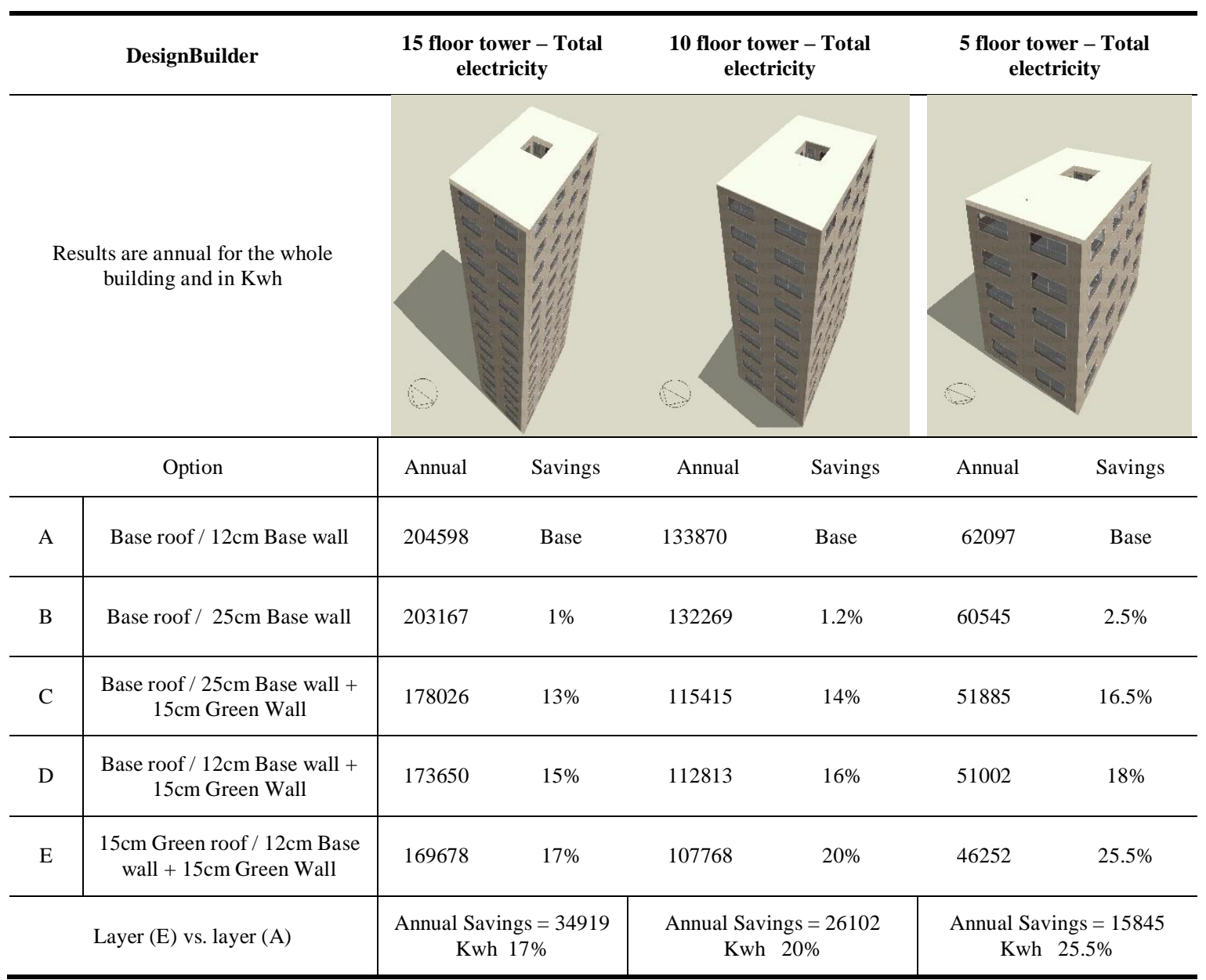

An interesting finding is green wall works better with a thinner brick layer in arid climate like Egypt, than a thicker one. An external envelop with no vegetation and $25 \mathrm{~cm}$ of brick wall performs better than a $12 \mathrm{~cm}$, which is common and predicted, however after adding a green layer on the $12 \mathrm{~cm}$ brick wall, it resulted in more energy savings than the $25 \mathrm{~cm}$ brick layer. This is due to lower thermal mass. This is good news for retrofitting existing buildings. The results confirm 
that there is significant Energy-saving potential in the application of green roofs and walls as an energy conservation strategy for buildings in arid climatic.

It is observed in Figure 2 that air cooling electricity consumption increases in April, May, June, July, August, September, and October due to increasing solar radiation in these months. Option E is the most effective layer, consumes less energy per annum than rest of layers A, B, C \& D. In general, air cooling accounts for $40 \%$ of annual electricity usage. The total yearly energy consumed by the base case model, option A (with $12 \mathrm{~cm}$ brick wall and without the vegetative layer) is $52,51,47 \mathrm{kWh} / \mathrm{m} 2$ per annum for different heights of $15,10 \& 5$ floors respectively, while green wall/roof option E reduced the total annual energy consumption of $43,41,35 \mathrm{kWh} / \mathrm{m} 2$ and, thus, a reduction of $17 \%$, $20 \% \& 25 \%$ of the total annual energy consumption is provided.

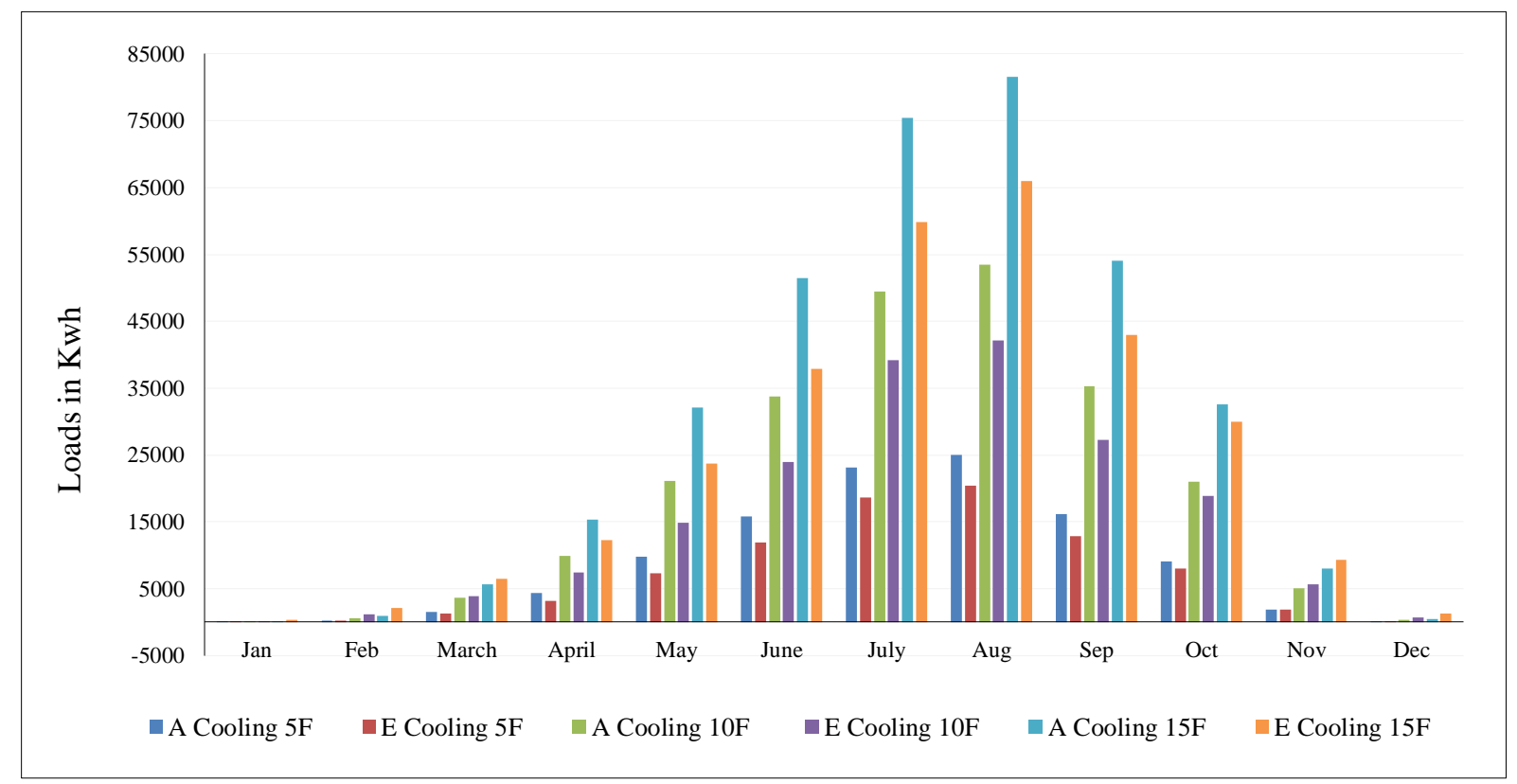

Figure 2. Air cooling annual loads between option A \& E (with/out greenery)

In order to validate the simulation results, a comparison between actual annual electricity consumption for a typical flat (170 m.sq) facing north south on the 10th floor of a residential building located in Cairo and its duplicate simulated with DesignBuilder using option B for external envelop. Aerial photo and August 2017 electricity receipt are shown in Figure 3. Results of the comparison shown in Figure 4 and implies very close consumption rates between the actual building and one simulated in the software. Differences are acceptable due to the dynamics of the human factor.
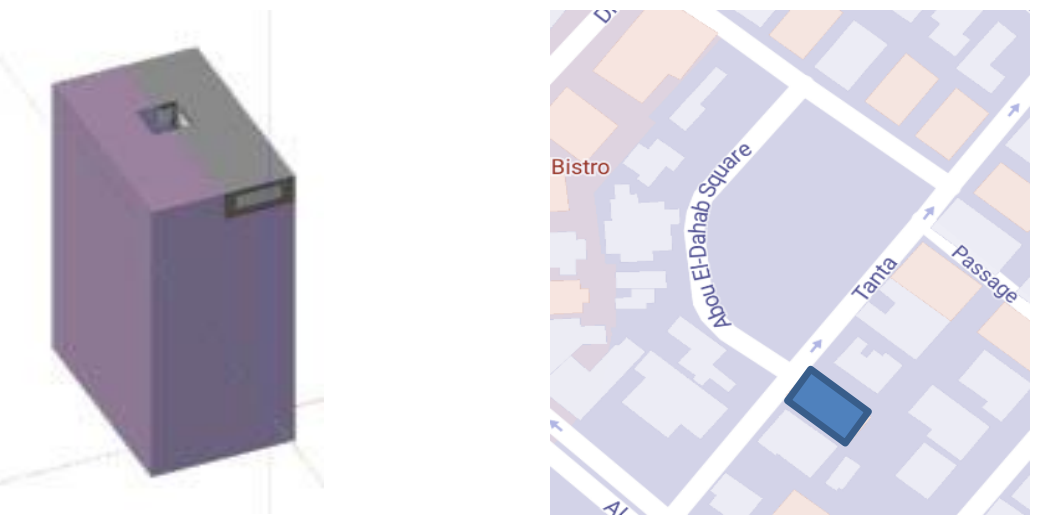

Figure 3. Showing Aerial photo for the actual building and August electricity receipt 


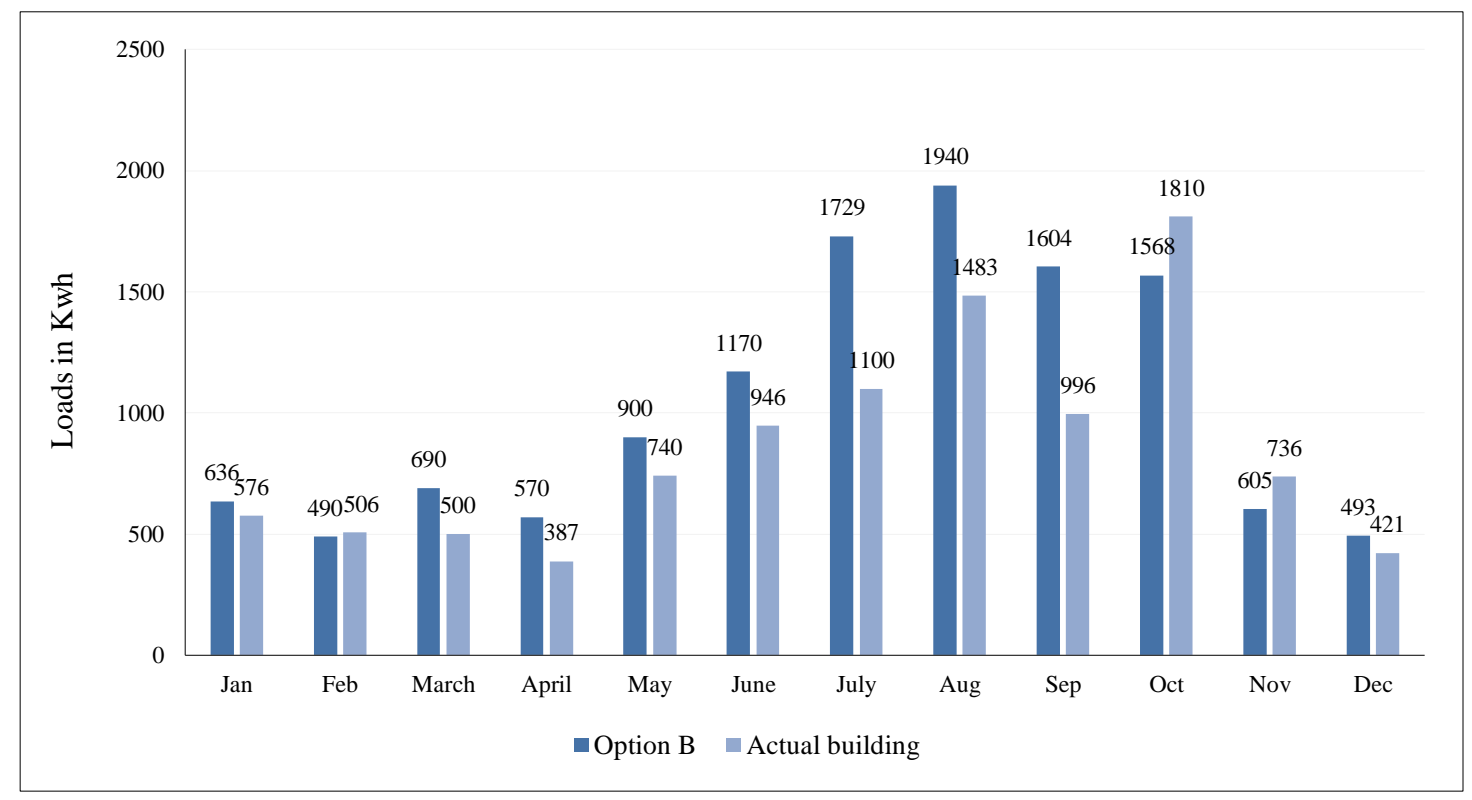

Figure 4. Annual electricity consumption for actual flat compared with simulated

Starting from 2014, Egyptian government signed to receive loans from the World Bank, the agreement was conditioned by removing electricity subsidies [44]. Today prices for $\mathrm{kWh}$ in residential electricity is $1.35 \mathrm{EGP}$ if consumption is between $650 \mathrm{kWh}$ and $1000 \mathrm{kWh}$ monthly and $0.90 \mathrm{EGP}$ if consumption is between $351 \mathrm{kWh}$ and 650 $\mathrm{kWh}$. In our simulated cases, monthly electricity consumption usually averages between the previously mentioned consumption rates. Results from Table 4 Adding green layer option E saves around 34919, 26101, 15845 kWh for the three different heights when compared to option A per annum, with an average price of $1.10 \mathrm{EGP}$ for $\mathrm{kWh}$ reflecting winter months less than $650 \mathrm{kWh}$ per month and summer months consumptions exceeding $650 \mathrm{kWh}$ per month, this is a huge amount of savings per annum with about 37500, 28700, 17400 EGP for the three different heights 15, 10, 5 Floors respectively. Results indicates the economic benefits of greenery when installed.

\subsection{Indoor Air Temperature and Comfort}

In order to measure the thermal effects of adding a green wall and roof on a building, a comparison is set to target a single zone inside one the building we previously investigated. An air conditioned rectangular zone of size Length $=8$ $\mathrm{m}$, width $=6 \mathrm{~m}$ and height $=3 \mathrm{~m}$ inherited from our simulated cases is considered in the study. This zone is considered a typical reception area, the traditional room represent option A without greenery and option $\mathrm{E}$ with greenery. The air conditioning unit is located on the West facing wall at the height of $2.7 \mathrm{~m}$ from the floor. The 3-dimensional model of the test case room is created in the CFD feature impeded in Designbuilder, CFD boundary condition and comfort calculations is shown in Table 6. Simulation occurs on the 2nd of August, hottest day in the year [45].

Table 6. CFD boundary configuration for single zone (with/ without greenery)

\begin{tabular}{|c|c|c|c|c|}
\hline CFD boundary & & Bare wall \& roof (a) & & Green wall and roof (e) \\
\hline Inside surface temperature-internal & 25 & & 25 & \\
\hline Inside surface temperature-external & 35 & & 35 & \\
\hline Inside surface window temperature & 30 & & 30 & \\
\hline Average zone air temperature & 40 & & 31 & \\
\hline Incoming air temperature & 34 & & 34 & \\
\hline \multicolumn{2}{|l|}{ Comfort calculation options } & & & \\
\hline Metabolic rate (met) & 0.9 & & 0.9 & \\
\hline Clothing Level (clo) & 1.0 & & 1.0 & \\
\hline Relative humidity (\%) & 50 & & 50 & \\
\hline
\end{tabular}




\subsubsection{Indoor Air Temperature}

The temperature variation across the room $A$ and $E$ simulated for the time of 1hr at 15:00, shown in Figure 5. In this figure, the temperature profile for the room with and without greenery is simulated. For the room Option (E) (with greenery) the temperature variation for the entire room's interior is $27^{\circ} \mathrm{C}$ except from small portion nearer to south and west facing wall has a temperature of $29^{\circ} \mathrm{C}$. However for the Option (A) room, zone nearer to roof, west wall and south have a temperature of $35^{\circ} \mathrm{C}$ and rest of the room portions is $33^{\circ} \mathrm{C}$. It is noticed that zone with green layers the variation is from $24^{\circ} \mathrm{C}$ to $29^{\circ} \mathrm{C}$, while the other zone with traditional external envelop is from $30^{\circ} \mathrm{C}$ to $35^{\circ} \mathrm{C}$. This shows indoor temperature reduction by $5^{\circ} \mathrm{C}$ at $15: 00$.

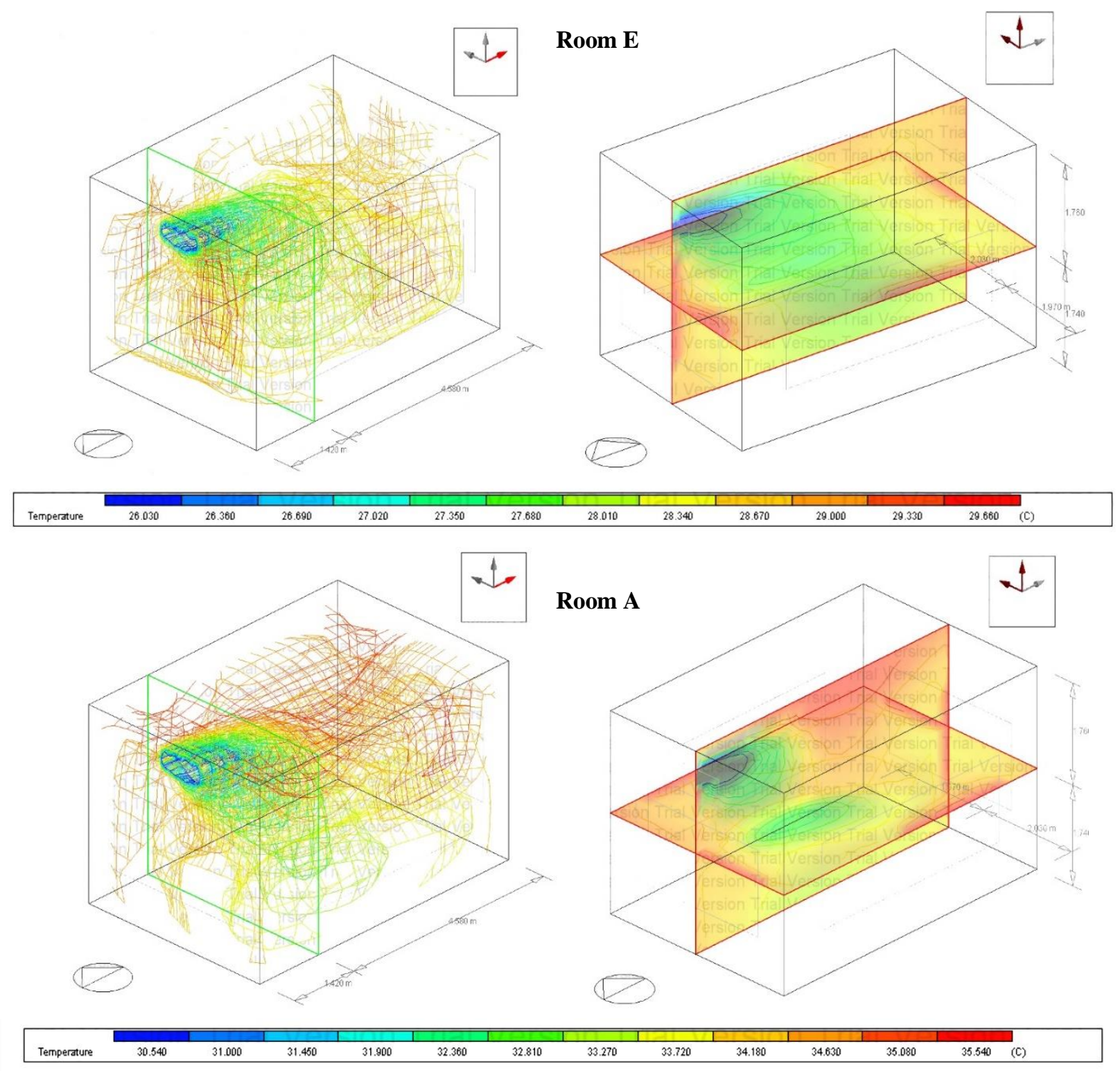

Figure 5. Zone Temperature distribution in room $\mathrm{E} \& \mathrm{~A}$ at 15Hr, 2nd of August

\subsubsection{Indoor Thermal Comfort}

Predicted mean vote (PMV) was used to discuss indoor thermal comfort in the warmest day. A higher PMV means stronger feeling of hotness. The PMV value has a range of +3.0 to 3.0, corresponding with the hot and cold thermal conditions. However in this study the PMV value reached 5 within the whole zone for the room A, which shows the intense effects of using $12 \mathrm{~cm}$ brick wall in construction in Arid climate. For room E, at 15:00 few portions nearer to the floor and the east facing wall have a PMV of 2 and rest of the portions attains the PMV of 1.5. The entire indoor is having average PMV of 1.7, Figure 6. Measuring PMV for one hour is not enough to compare the comfort performance, but it is an indicator for poor performances of thin bricks in Cairo and a catalyst for better envelop solutions. 

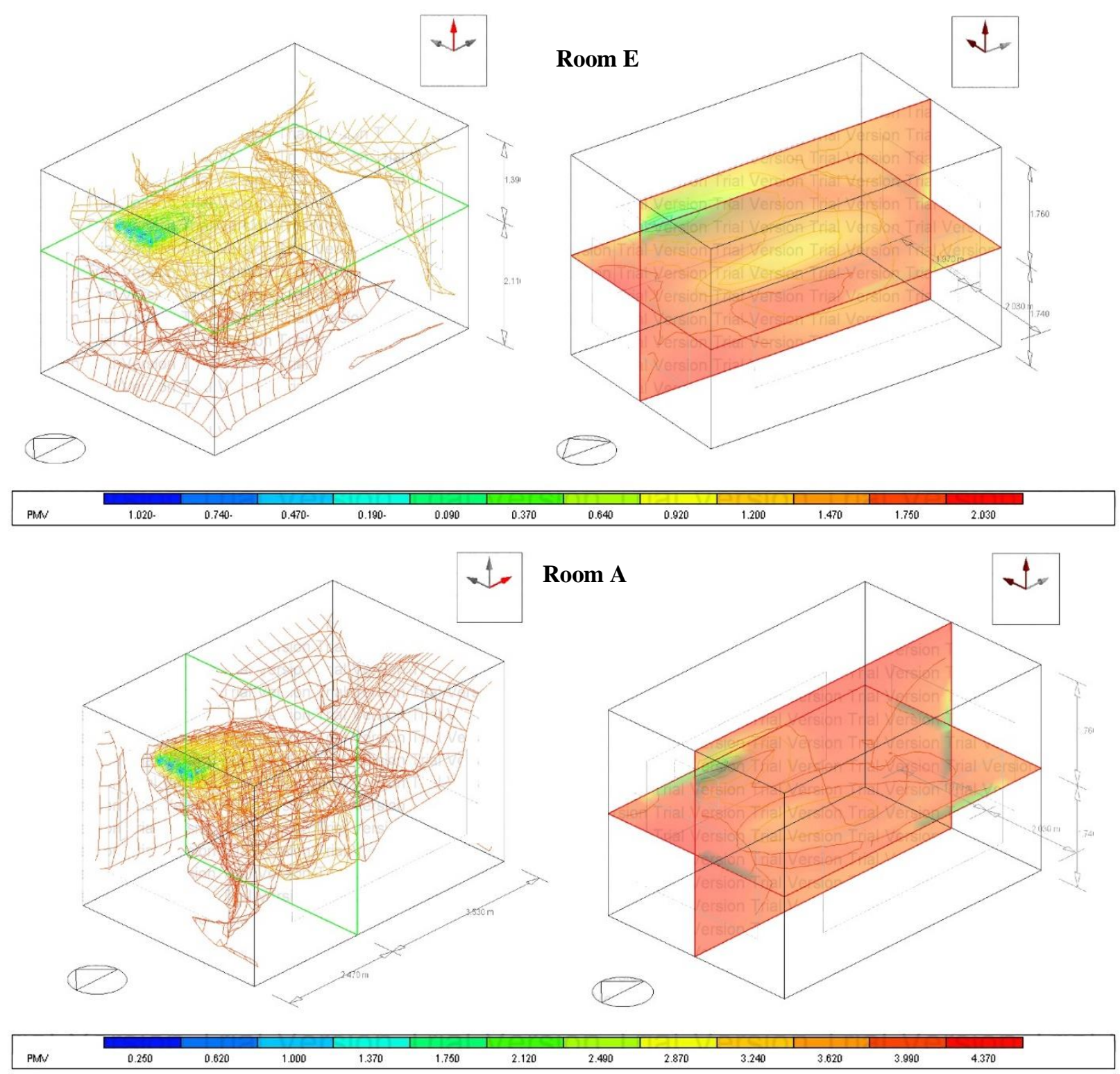

Figure 6. PMV measures for room A \& E respectively at 15hr, 2nd of August

Further increase in the thickness wall layer and adding a green roof and green wall of $15 \mathrm{~cm}$ soil thickness, reduces the average indoor PMV by 3 and reduces the entry of solar radiation. Hence the cooling energy consumed by the air conditioning units will be effectively utilized to keep indoor in a desired comfort level. About $43 \%$ reduction in electricity resulted between room $\mathrm{A}$ and $\mathrm{E}$.

\subsection{Operational Carbon and Emission Reduction}

The production of concrete and steel/iron are two of the five primary industries that contribute to nearly one-quarter of the carbon dioxide emissions annually. To see the true carbon offset potential of a green layer (roof or wall), there is a need to look at it from a cradle-to-cradle perspective. This would include taking into account the carbon dioxide emitted from the materials used to construct the roof and the wall. For the purposes of this commentary, operation emissions is the only phase that will be highlighted for our study. The amount of carbon dioxide emissions avoided through energy savings from green roofs and wall is illustrated in Figure 7. Option A compared to option E for the three different building heights. Peak $\mathrm{CO}_{2}$ emissions is in August in all cases, due to heat gain and increased solar radiation. Option E (with greenery) emits less carbon than option A for the three different heights with 35140,16200 and $8365 \mathrm{~kg}$ of carbon respectively. This accounts for $15 \%, 10 \%$ and $7 \%$ reduction between traditional external envelop and green envelop. 


\section{Conclusion}

Green roofs and walls play an important role in reducing the urban heat island effect. Green layers reduce the amount of energy needed to control the internal temperature of the building and reducing energy consumption. While providing interior temperature moderation, during warm months a green envelop increases evapotranspiration, thus cooling the surrounding air. Our findings showed that a green layer in arid climate is a good choice for building environmental solution. A green layer have a high ability to reduce electricity, $\mathrm{CO}_{2}$ emissions and enhance indoor comfort.

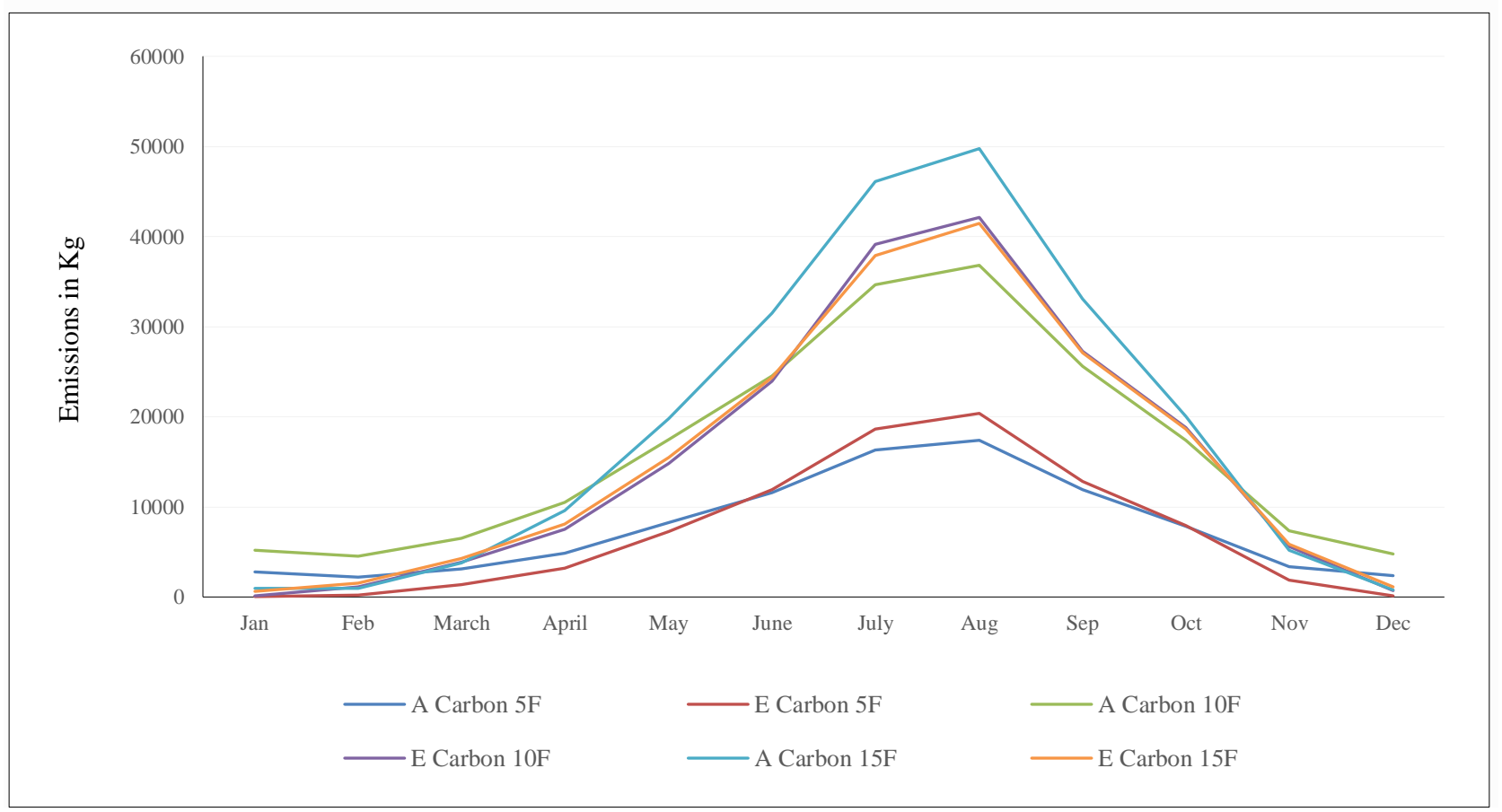

Figure 7. Annual Carbon production option A \& E (with/ greenery) for three heights

In this study, no comparison was made between extensive and intensive green roof types. The harsh exterior weather conditions in Egypt are an obstacle to the application of intensive green roof types as it causes more thermal storage which leads to more air cooling usage. In addition, an external envelop with no vegetation and $25 \mathrm{~cm}$ of brick wall performs better than a $12 \mathrm{~cm}$ brick envelop. After adding a green layer to the $12 \mathrm{~cm}$ brick wall, it resulted in more energy savings than the $25 \mathrm{~cm}$ with greenery, this is due to decreased thermal storage over the day.

The case study showed that that air cooling electricity consumption accounts for $40 \%$ of total annual electricity. The energy consumption for the base case (without greenery) consumed $52 \mathrm{kWh} / \mathrm{m}^{2}$ annually, while the energy consumption due to the application of greenery ( $100 \%$ coverage) reduced consumption to $43 \mathrm{kWh} / \mathrm{m}^{2}$ annually. For the three investigated building heights (5, 10, 15 floors), energy saving is found to be in the range of $17 \%$ to $25 \%$ respectively. This reflects a huge economic saving annually ranging between 17,000 to 37,000 EGP.

Indoor comfort simulation in this research indicated that a building with poor envelop solution (without greenery) in arid climate when exposed to solar radiation have a great influence on indoor thermal environment (larger solar radiation resulted higher value of PMV), and the energy consumption of air-conditioner in the building was much higher. Results proved the building with green envelop reduced indoor air temperature by $5^{\circ} \mathrm{C}$ at 15:00 and the PMV by 3 values. In such way, green cities matching building design with its environment, can witness a more efficient and sustainable future of the energy-saving. Future researches could further focus on economic trade-offs when installing a green layer in arid climates.

\section{References}

[1] Mujeebu, M.A. and Alshamrani, O.S., "Prospects of energy conservation and management in buildings-The Saudi Arabian scenario versus global trends". Sustain. Energy Rev. 2016, Vol. 58, PP. 1647-1663. https://doi.org/10.1016/j.rser.2015.12.327.

[2] Suganthi, L. and Samuel, A.A. "Energy models for demand forecasting-A review". Sustain. Energy Rev. 2012, Vol.16, PP.12231240. https://doi.org/10.1016/j.rser.2011.08.014.

[3] Asif, M. "Urban Scale Application of Solar PV to Improve Sustainability in the Building and the Energy Sectors of KSA". Sustainability 2016, Vol. 8. https://doi.org/10.3390/su8111127.

[4] Muneer, T.; Asif, M.; Cizmecioglu, Z.; Ozturk, H.K. "Prospects for solar water heating within Turkish textile industry". Renew. Sustain. Energy Rev. 2008, Vol. 12, PP. 807-823. https://doi.org/10.1016/j.rser.2006.10.024. 
[5] Asif, M. and Muneer, T. "Energy supply, its demand and security issues for developed and emerging economies". Renew. Sustain. Energy Rev. 2007, Vol. 11, PP. 1388-1413. https://doi.org/10.1016/j.rser.2005.12.004.

[6] Terés-Zubiaga, J.; Campos-Celador, A.; González-Pino, I.; Escudero-Revilla, C. "Energy and economic assessment of the envelope retrofitting in residential buildings in Northern Spain". Energy Build. 2015, Vol.86, PP.194-202. https://doi.org/10.1016/j.enbuild.2014.10.018.

[7] Asif, M. "Energy Crisis in Pakistan: Origins, Challenges, and Sustainable Solutions"; Oxford University Press: Karachi, Pakistan, 2012. https://doi.org/10.1108/17542431111185213.

[8] UNEP SBCI. "Buildings and Climate Change: Summary for Decision-Makers; United Nations Environmental Program", Sustainable Buildings and Climate Initiative: Paris, France, 2009.

[9] Alnaser, N.W., Flanagan, R., Alnaser, W.E. "Model for calculating the sustainable building index (SBI) in the kingdom of Bahrain". Energy Build. 2008, Vol. 40, PP. 2037-2043. https://doi.org/10.1016/j.enbuild.2008.05.015.

[10] Asif, M. "Growth and sustainability trends in the buildings sector in the GCC region with particular reference to the KSA and UAE". Sustain. Energy Rev. 2016, Vol. 55, PP. 1267-1273. https://doi.org/10.1016/j.rser.2015.05.042.

[11] N. Kohler and W. Yang. "Long-term management of building stocks". Building Research \& Information, 2007; p. 35:351. https://doi.org/10.1080/09613210701308962.

[12] C. Sjöström. Sustainable construction\& performance based standards \&codes 2000.

[13] Azis, A. Memon, I. Rahman, S.Nagapan, Q. Latif. "Challenges faced by construction industry in accomplishing sustainability goals". 2012 IEEE Symposium on Business, Engineering\& Industrial Applications (ISBEIA), 2012, PP. 4-630. https://doi.org/10.1109/isbeia.2012.6422966.

[14] A.Hassanein and S.Adly. Small Egyptian Construction Firms: The Financing Barrier. Oxford Business Economics Conference Program, Retrieved; 2008. https://doi.org/10.1080/08276331.2008.10593430.

[15] S.Michel and H. Elsayed. Examples of flow energy design at urban scale in Egypt. PLEA, Switzerland, Geneva2006.

[16] B. Basarir, et al., "Energy Efficient Retrofit Methods at the Building Envelopes of the School Buildings", Retrieved $1012,2016$. <www.academia.edu/Ellipsis/Energy_efficient_retrofit_methods_at_the_building_envelopes>, 2012.

[17] HBRC, Egyptian Code for Energy Efficiency in Buildings, ECP306-2205, Second Section (306-2), Ministry of Housing, Arab Republic of Egypt, 2009.

[18] Radwana et al, "Retrofitting of existing buildings to achieve better energy efficiency in commercial building case study: hospital in Egypt, Alexandria" Eng. J. 55, 2016, Vol. 4, PP. 3061-3071. https://doi.org/10.1016/j.aej.2016.08.005.

[19] M. Aboulnaga, et al., "Sustainability of Higher Educational Buildings: Retrofitting approach to improve energy performance and mitigate CO2 emissions in hot climates", Energy Environ. Sustain. 2016. https://doi.org/10.1051/rees/2016016.

[20] Attia, Shady, Arnaud Evrard, and Elisabeth Gratia. "Development of Benchmark Models for the Egyptian Residential Buildings Sector.” Applied Energy 94 (June 2012): 270-284. doi:10.1016/j.apenergy.2012.01.065.

[21] Nasir, R.A., Ahmad, S.S., Zain-Ahmed, A., Ibrahim, N. "Adapting Human Comfort in an Urban Area: "The Role of Tree Shades towards Urban Regeneration". Proceed. Soc. Behav. Sci. 2015, Vol. 170, PP. 369-380. https://doi.org/10.1016/j.sbspro.2015.01.047.

[22] De Abreu-Harbich, L.V.; Labaki, L.C.; Matzarakis, A. "Effect of tree planting design and tree species on human thermal comfort in the tropics". Landsc. Urban Plan. 2015, Vol. 138, PP. 99-109. https://doi.org/10.1016/j.landurbplan.2015.02.008.

[23] Hong, B. and Lin, B. "Numerical studies of the outdoor wind environment and thermal comfort at pedestrian level in housing blocks with different building layout patterns and trees arrangement". Energy 2015, Vol.73, PP. 18-27. https://doi.org/10.1016/j.renene.2014.05.060.

[24] Vailshery, L.S.; Jaganmohan, M.; Nagendra, H. "Effect of street trees on microclimate and air pollution in a tropical city". Urban For. Urban Green. 2013, Vol. 12, PP. 408-415. https://doi.org/10.1016/j.ufug.2013.03.002.

[25] Shashua-Bar, L.; Tsiros, I.X.; Hoffman, M.E. "A modelling study for evaluating passive cooling scenarios in urban streets with trees". Case study: Athens, Greece. Build. Environ. 2010, Vol. 45, PP. 2798-2807. https://doi.org/10.1016/j.buildenv.2010.06.008.

[26] Santamouris, M. "Cooling the cities - A review of reflective and green roof mitigation technologies to fight heat island and improve comfort in urban environments". Sol. Energy 2014, Vol. 103, PP. 682-703. https://doi.org/10.1016/j.solener.2012.07.003.

[27] Chen, H.; Ookab, R.; Huang, H.; Tsuchiyab, T. "Study on mitigation measures for outdoor thermal environment on present urban blocks in Tokyo using coupled simulation". Build. Environ. 2009, Vol. 44, PP. $2290-2299$. https://doi.org/10.1016/j.buildenv.2009.03.012.

[28] Smith, K. and Roeber, P. "Green roof mitigation potential for a proxy future climate scenario in Chicago", Illinois. J. Appl.. 2011, Vol. 50, PP. 507-522. https://doi.org/10.1175/2010jamc2337.1.

[29] De Munck, C. "Modélisation de la végétation urbaine et stratégies d'adaptation pour l'amélioration du confort climatique et de la demande énergétique en ville'. Ph.D. Thesis, University de Toulouse, Toulouse, France, 2013. (In French).

[30] Ascione, F.; Bianco, N.; de' Rossi, F.; Turni, G.; Vanoli, G.P. "Green roofs in European climates. Are effective solutions for the energy savings in air-conditioning". Appl. Energy 2013, Vol. 104, PP. 845-859. https://doi.org/10.1016/j.apenergy.2012.11.068.

[31] Susorova, I.; Angulo, M.; Bahrami, P.; Stephens, B. "A model of vegetated exterior facades for evaluation of wall thermal 
performance". Build. Environ. 2013, Vol. 67, PP. 1-13. https://doi.org/10.1016/j.buildenv.2013.04.027.

[32] Chen, Q.; Li, B.; Liu, X. "An experimental evaluation of the living wall system in hot and humid climate". Energy Build. 2013, Vol. 61, PP. 298-307. https://doi.org/10.1016/j.enbuild.2013.02.030.

[33] Wong, N.H.; Tan, A.Y.K.; Tan, P.Y.; Wong, N.C. "Energy simulation of vertical greenery systems". Energy Build. 2009, Vol. 41, PP. 1401-1408. https://doi.org/10.1016/j.enbuild.2009.08.010.

[34] Hoyano, A. Climatological uses of plants for solar control and the effects on the thermal environment of a building. Energy Build. 1988, 11, 181-199. https://doi.org/10.1016/0378-7788(88)90035-7.

[35] Cameron, R.W.F.; Taylor, J.E.; Emmett, M.R. "What's "cool" in the world of green facades? How plant choice influences the cooling properties of green walls". Build. Environ. 2014, Vol. 73, PP. 198-207. https://doi.org/10.1016/j.buildenv.2013.12.005.

[36] Alexandri, E.; Jones, P. "Temperature decreases in an urban canyon due to green walls and green roofs in diverse climates". Build. Environ. 2008, Vol. 43, PP. 480-493. https://doi.org/10.1016/j.buildenv.2006.10.055.

[37] Djedjig, R.; Bozonnet, E.; Belarbi, R. "Analysis of thermal effects of vegetated envelopes: Integration of a validated model in a building energy simulation program". Energy Build. 2015, Vol. 86, PP. 93-103. https://doi.org/10.1016/j.enbuild.2014.09.057.

[38] Francis, L.F.M.; Jensen, M.B. Benefits of green roofs: A systematic review of the evidence for three ecosystem services. Urban For. Urban Green. 2017, 28, 167-176. https://doi.org/10.1016/j.ufug.2017.10.015.

[39] D.J. Sailor, "A green roof model for building energy simulation programs", Energy Build. 2008, Vol. 40, PP. $1466-1478$. https://doi.org/10.1016/j.enbuild.2008.02.001. https://doi.org/10.1016/j.enbuild.2008.02.001.

[40] D.J. Sailor; T.N. Rosenstiel; C.C. Wamser, "Modeling impacts of roof reflectivity, integrated photovoltaic panels and green roof on sensible heat flux into the urban environment", Build. Environ. 2011, Vol. 46, PP. $2542-2551$. https://doi.org/10.1016/j.buildenv.2011.06.012.

[41] S.S. Moody, D.J. Sailor, Development and application of a building energy performance metric for green roof, Energy Build. 2013, Vol. 60, PP. 262-269. https://doi.org/10.1016/j.enbuild.2013.02.002.

[42] Pianella, R.E. Clarke, N.S.G. Williams, Z. Chen, L. Aye, Steady-state and transient thermal measurements of green roof substrates, Energy Build. 2016, Vol. 131, PP. 123-131. https://doi.org/10.1016/j.enbuild.2016.09.024.

[43] Kamel, B.; Wahiba, S.; Nassar, K.; Abdelsalam, A. Effectiveness of green roof on reduction of energy consumption through simulation program for a residential building: Cairo, Egypt. In Proceedings of the Construction Research Congress, West Lafayette, Indiana, 21-23 May 2012. https://doi.org/10.1061/9780784412329.175.

[44] World Bank. 2017. Energy Subsidy Reform Facility Country Brief: Egypt. Available at: http://documents.worldbank.org [Accessed 16 July 2018].

[45] Weather spark. 2018. Average Weather in Cairo Egypt. Available at: https://weatherspark.com/ [Accessed 15 July 2018]. 